\title{
Octoblepharum benitotanii (Octoblepharaceae) a new species from the Old World Tropics
}

\author{
Noris Salazar Allen ${ }^{* 1}$ and Sahut Chantanaorrapint ${ }^{2}$
}

\begin{abstract}
Octoblepharum benitotanii Salazar Allen \& Chantanaorr., a new species of Octoblepharum from the Old World tropics, is described and illustrated based on specimens from Thailand and Timor. Taxonomic affinities and information on habitat and distribution are discussed. This is the fourth species of Octoblepharum described for Asia besides $O$. albidum, $O$. arthrocormoides, and $O$. pocsii and, not counting $O$. depressum, whose type specimen has not been found and thus its status is doubtful. Octoblepharum benitotanii is distinguished by its narrow, elongate, tumid, long acuminate leaves and peristome with eight foveolate-reticulate teeth.
\end{abstract}

KEYWORDS: Bryophyta, Octoblepharum albidum, species-complex, Southeast Asia

\section{INTRODUCTION}

Octoblepharum Hedw. is a pantropical moss genus with 18 species recognized worldwide (Wijk et al., 1964, 1969; Crum, 1983; Salazar Allen, 1991, 1992, 1994; Yano, 1992; Salazar Allen \& Tan, 2010; Magill \& Allen, 2013; He, 2014). Six species are known from Australia, Asia and Oceania $(O$. albidum Hedw., O. arthrocormoides Salazar Allen \& B.C. Tan, O. cylindricum Schimp. ex Mont., $O$. depressum Müll. Hal., $O$. exiguum Müll. Hal. and $O$. pocsii Magil \& B.H. Allen). The type of $O$. depressum from Asia has not been found. Also missing is the type of $O$. exiguum, endemic to Australia, which probably is a small form of $O$. albidum (according to $D$. Catcheside, unpublished manuscript). The locality in Tahiti of O. cylindricum reported by Yano (1992) that appears in the label at R (R80280) (per visum Salazar Allen) has not been found. Also Octoblepharum leptoneuron Card. has not been recorded for these regions as indicated in Salazar Allen \& Tan (2010). Five species are reported for Africa: $O$. africanum (Broth.) Cardot, O. albidum, O. brevisetum Townsend, $O$. leptoneuron and $O$. pocsii. Of these, $O$. brevisetum appears

${ }^{1}$ Smithsonian Tropical Research Institute, Apartado 0843-03092, Balboa, Ancón, Republic of Panama

${ }^{2}$ PSU Herbarium, Department of Biology, Faculty of Science, Prince of Songkla University, Hat Yai, Songkhla 90112, Thailand.

*Corresponding author: salazarn@si.edu

Date Submitted: 02 February 2018

Date Accepted: 28 March 2018 to be a small form of $O$. albidum (Egunyomy et al., 1977). Nevertheless it has not yet been formally synonymized.

Twelve species are known for the Neotropics: $O$. albidum, $O$. africanum, $O$. ampullaceum Mitt., $O$. cocuiense Mitt., $O$. costatum H.A. Crum, $O$. cylindricum, $O$. erectifolium Mitt., O. leucobryoides O. Yano, O. pulvinatum (Dozy \& Molk.) Mitt., $O$. rhaphidostegium Müll. Hal., O. stramineum Mitt. and O. tatei (Williams) E.B. Bartram (Crum, 1983, Yano, 1992; Salazar Allen \& Tan, 2010). The status of $O$. costatum is doubtful. Based on the description by Crum in 1983, Frahm (1994) suggested that this species could be a synonym of $O$. cocuiense.

Taxonomic revision of the Neotropical species of Octoblepharum led us to study additional specimens from the Old World tropics, particularly of the worldwide distributed 0 . albidum. In Neotropical collections studied, this species showed more variation in peristome ornamentation than in gametophytic characters. Peristome teeth in this species can be triangular in shape, smooth to vertically striated with or without perforations, or teeth can be elongated with perforations and fragile. Thus, $O$. albidum appears to be a complex of cryptic species, with very close gametophytic morphology but distinct variation in peristome structure and ornamentation. During a trip to European herbaria in 2016, the senior author examined samples of $O$. albidum from Southeast Asia and Africa. Some specimens exhibited the same variations observed in Neotropical samples. Nonetheless, there were a couple of 
collections from Southeast Asia that showed a distinct peristome structure and variations in gametophytic characters not observed in Neotropical specimens nor in the recently published O. pocsii (Magill \& Allen, 2013). Upon further examination these collections are herein recognized as representing a new species.

\section{MATERIALS AND METHODS}

Morphological studies were based on the revision of specimens received on loan by Salazar Allen from $M$, and a revision of samples by the junior author, from PSU, CMUB (herbarium acronyms follow Thiers, 2018) and fresh samples collected. Microscopic examination and measurements were taken with a Leica-MZ6 stereomicroscope (SM) and an Olympus-BX50 light microscope (LM), while microphotographs were obtained with an Olympus-DP25 digital camera mounted on that microscope. Cross-sections of mature leaves were made at their base, above the hyaline lamina and at their apex. Procedures for preparation of samples for scanning electron microscopy (SEM) followed a modification of the methodology used by Salazar Allen (1993). Micrograph images were digitized using a Zeiz Evo 40 vp SEM with a backscattered electron detector and an acceleration voltage of $25 \mathrm{kV}$ setting.

\section{TAXONOMIC TREATMENT}

Octoblepharum benitotanii Salazar Allen \& Chantanaorr., sp. nov. (Figs. 1-8).

TYPE -Thailand: Prov. Chiang Mai, 525 m, 18 Nov. 2010, J.F. Maxwell B-213 (holotype CMUB; isotype, M).

\section{Diagnosis}

Octoblepharum benitotanii is similar to $O$. albidum in habit, its swollen hyalocysts on leaf margin, its autoicous condition, and the possession of eight peristome teeth, but differs in its distinctive longly acuminate leaves and the possession of peristome teeth that are dorsally and ventrally strongly foveolate-reticulate.

Plants perennial, glaucous green, in loose tufts. Stems $0.5-$ $1.2 \mathrm{~cm}$ tall, without a central strand branching below the perichaetia. Leaves long, adpressed when dried, widely spreading when wet, tumid, erect to recurved from above hyaline lamina, (3-) $4.5-5.5(-6) \times 0.4-0.5 \mathrm{~mm}$, apices each with a prominent acumen (110-)128 - 166(-177) $\mu \mathrm{m}$ long, composed of a long single projecting cell, flanked by two adjacent cells; margins slightly undulate due to swollen hyalocysts, the hyalocysts single or in groups of $2-3$, limbidium extending proximally from leaf apex to apex of hyaline lamina, 1 - 2 thick-walled, linear cells wide; hyaline lamina unistratose composed of thin-walled hyalocysts, the hyalocysts long to short, hexagonal at apex of lamina, quadrate at mid-lamina next to costa, and rectangular to quadrate basally; costa composed of ventral and dorsal layers of hyalocysts supporting a unistratose, median network of small, thick-walled chlorocysts, in cross-section chlorocysts forming an irregularly zigzagging row, quadrate and triangular in leaf base and, triangular to tear-shaped above, the chlorocysts at leaf bases surrounded by $5-8(-9)$ layers of porose hyalocysts, the hyalocysts in $5-7$ rows dorsally and, $2-3$ rows ventrally, at midleaf in $3-4$ rows dorsally, and $4-5$ rows ventrally and, at apex, in $3-4$ rows on both sides of leaf. Autoicous, perigonia axillary in short branches below archegonia, antheridia surrounded by $3-4$ small hyaline leaves, perichaetia terminal. Setae yellow below, light to dark orange above, smooth, $2.5-3.0 \mathrm{~mm}$ long. Capsules red to orange-red, cylindrical, $1.3-2.2(-3)$ $\mathrm{mm}$ long, exothecial cells at mouth dark red with equally thin walls, quadrate and pentagonal, cells below rectangular with thick longitudinal walls and thin transversal walls, cells variable in size, oblong-quadrate to long rectangular, 38 - 80 $\mu \mathrm{m}$ long, shorter at base, with phaneropore stomata at base. Prostomes of $6-8$ rows of cells. Peristomes inserted in the mouth of the capsule, teeth 8 , thick, sometimes with perforations near the base, strongly foveolate-reticulate on dorsal and ventral surfaces, trabeculae faint. Opercula long to short rostrate, straight to curved. Calyptrae cucullate, smooth, yellow to dark red at apex, $1.2-1.3 \mathrm{~mm}$ long. Spores spheroid, (15-)20 - 23(-25) $\mu \mathrm{m}$ in diameter, brown, densely gemmate.

Eponymy: This species is named in honor of the late Dr. Benito Tan (1946-2016), a distinguished bryologist studious of the Asian bryophyte flora.

Distribution: Octoblepharum benitotanii is only known from Thailand and Indonesia in West Timor and in West Java province (Fig. 8). Nevertheless, it is possible that the species is widely distributed in other areas of Southeast Asia and may have been misidentified as $O$. albidum as were the specimens cited herein.

Habitat: Octoblepharum benitotanii grows on tree trunks, branches and rotten woods in beach, lowland dry evergreen, deciduous, and dipterocarp forests; at elevations from near the sea-level to $1650 \mathrm{~m}$ a.s.l.

\section{DIscussion}

Of the seven recognized species of Octoblepharum with 8 peristome teeth (i.e., 0 . albidum, $O$. ampullaceum, 0 . brevisetum, 0 . costatum, 0 . cylindricum, 0 . erectifolium, $O$. pocsii and $O$. rhaphidostegium), the closest to $O$. benitotanii in gametophytic characters is $O$. albidum. These two 


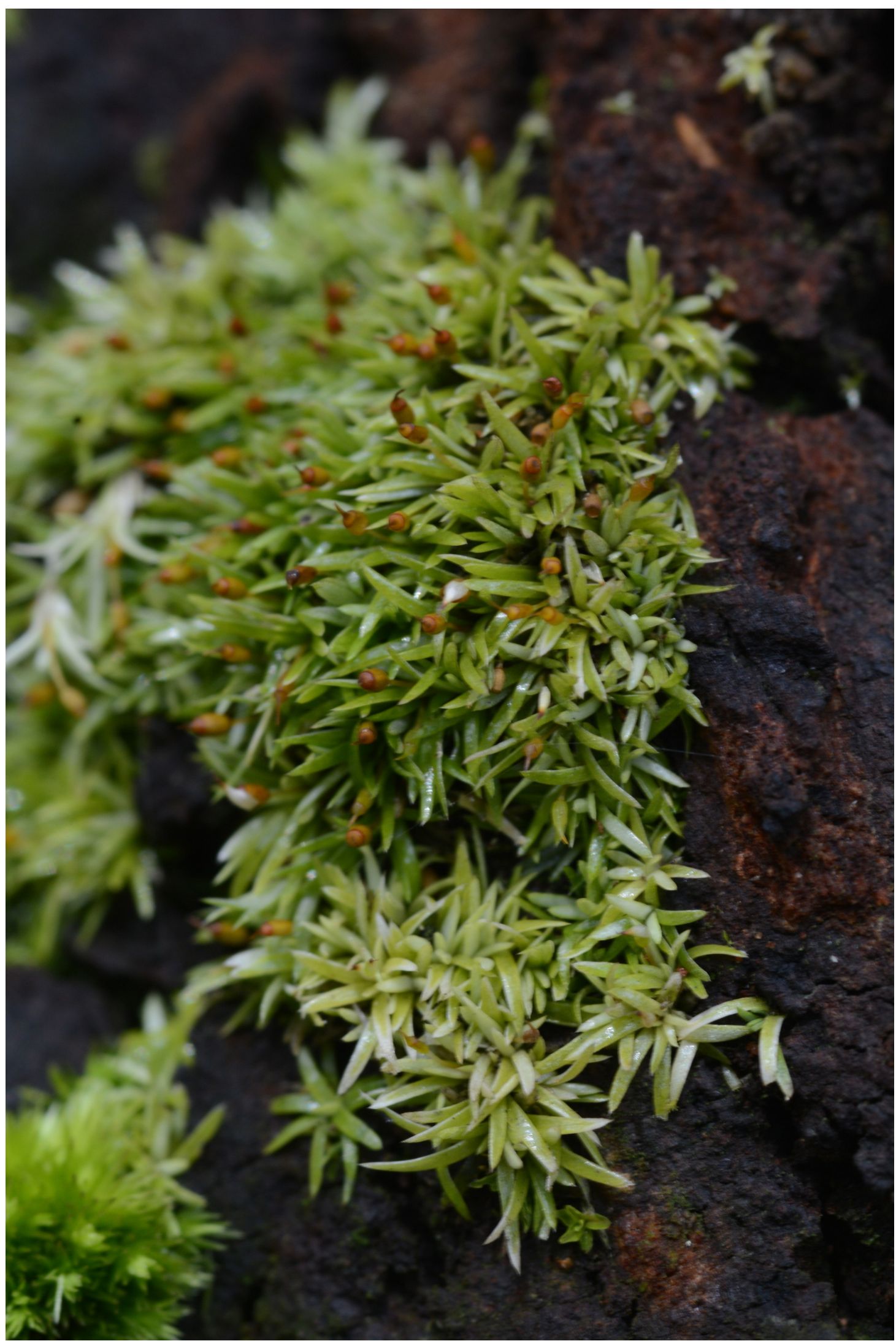

Figure 1. Octoblepharum benitotanii Salazar Allen \& Chantanaorr., sp. nov. Habit of plant in its natural environment. 

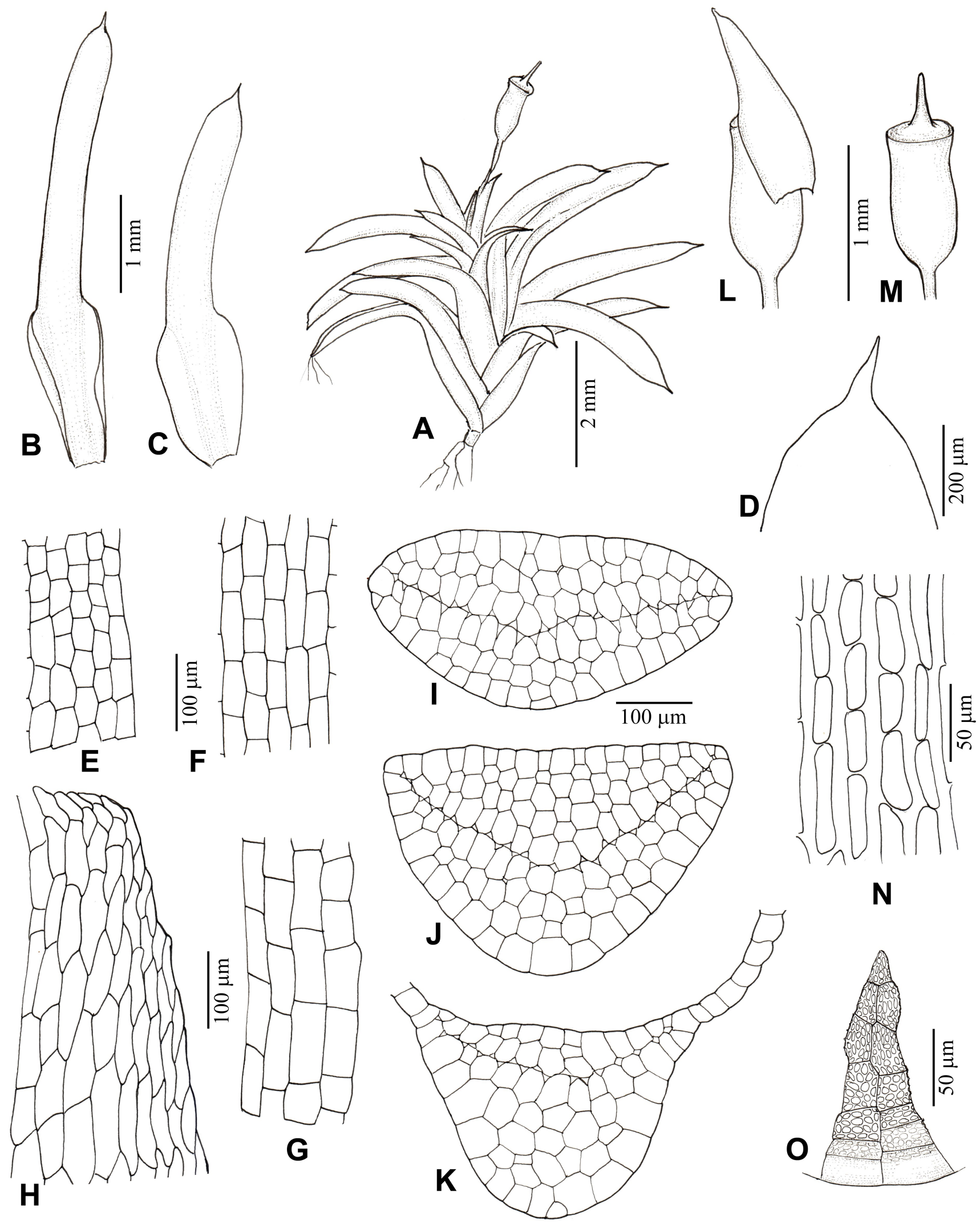

Figure 2. Octoblepharum benitotanii Salazar Allen \& Chantanaorr., sp. nov. A. Gametophyte with sporophyte; B-C. Leaves; D. Leaf apex; E-G. Upper cells of leaf lamina; E. Near apex, F. At mid-leaf, G. Near base; H. Marginal cells of leaf hyaline lamina; I-K. Cross sections of the leaf, I. Near apex, J. At mid-leaf, K. Near base; L. Capsule covered with calyptra; M. Mature capsule with operculum; N. Exothecial cells of capsule; O. Peristome tooth, dorsal (outer) surface. From holotype, J.F. Maxwell B-213 (CMUB). 

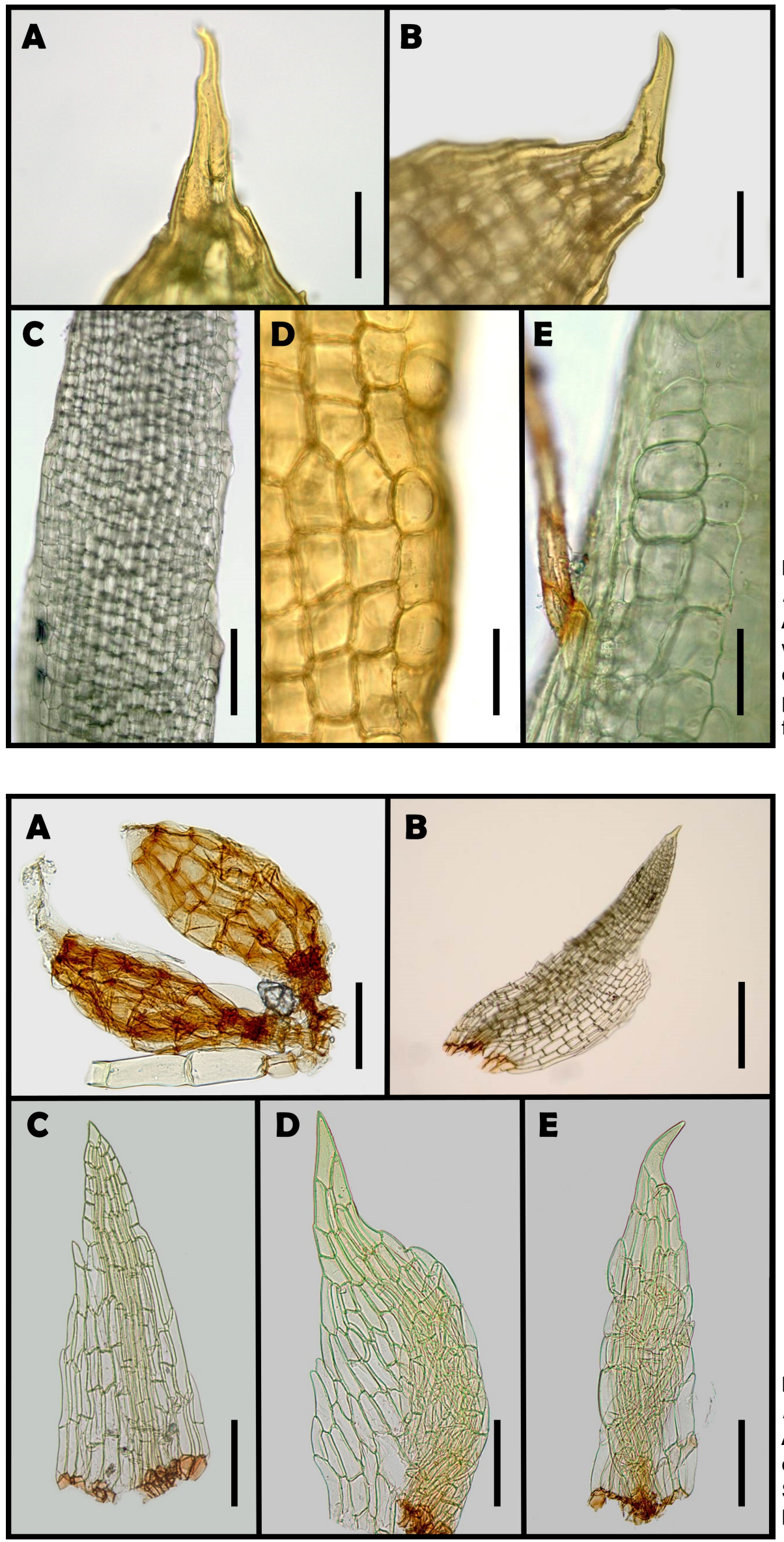

Figure 3. Leaf characters of Octoblepharum benitotanii Salazar Allen \& Chantanaorr., sp. nov. A-B. Apices of leaves; C. Undulate leaf margin with inflated hyalocysts; D-E. Inflated hyalocysts on leaf margin. Scales: $A=58.2 \mu \mathrm{m}, B=53.3$ $\mu \mathrm{m}, \mathrm{C}=0.19 \mathrm{~mm}, \mathrm{D}=43.4 \mu \mathrm{m}, \mathrm{E}=35.5 \mu \mathrm{m}$. All from isotype.
Figure 4. Male gametangia of Octoblepharum benitotanii Salazar Allen \& Chantanaorr., sp. nov. A. Mature antheridia, the left antheridium discharging gametes; B-E. Perigonial leaves. Scales: $\mathbf{A}=55.2 \mu \mathrm{m}, \mathbf{B}=0.27 \mathrm{~mm}, \mathbf{C}=0.14 \mathrm{~mm}$, $D=76.3 \mu \mathrm{m}, E=80.6 \mu \mathrm{m}$. All from isotype. 

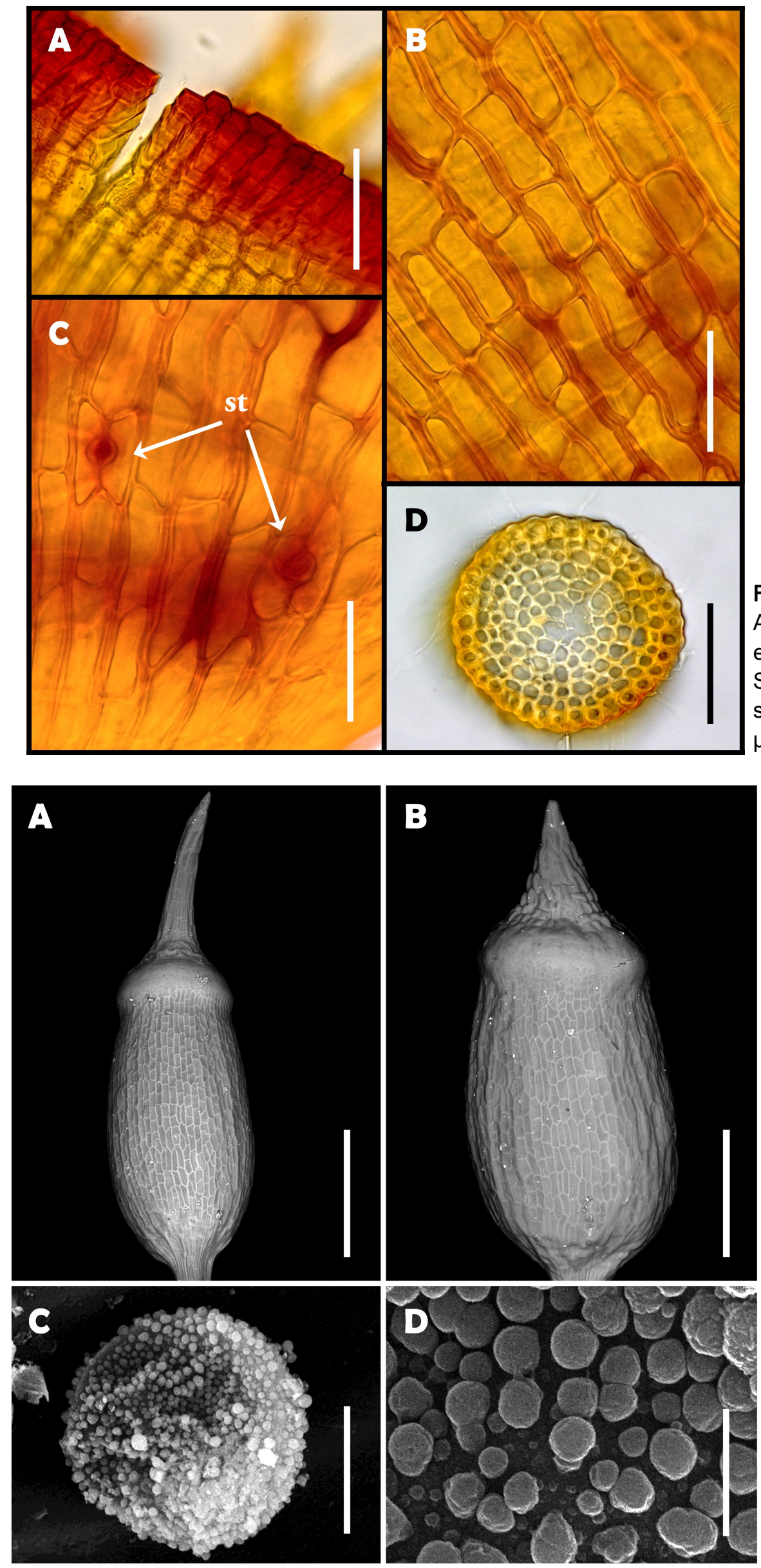

Figure 5. Octoblepharum benitotanii Salazar Allen \& Chantanaorr., sp. nov. A. Upper exothecial cells; B. Mid-exothecial cells; C. Stomata (st) at base of capsule; D. Cross section of seta. Scales: $A$ \& $D=80 \mu \mathrm{m}, \mathrm{B}=64$ $\mu \mathrm{m}, \mathrm{C}=63.5 \mu \mathrm{m}$. All from isotype.

Figure 6. Scanning electron micrographs of sporophyte of Octoblepharum benitotanii Salazar Allen \& Chantanaorr., sp. nov. A-B. Observed variations in size of operculum; C. Spore; D. Gemmate exine of spore. Scales: A $=0.54 \mathrm{~mm}, \mathbf{B}=0.35 \mathrm{~mm}, \mathbf{C}=11.3 \mu \mathrm{m}, \mathbf{D}=$ $2.38 \mu \mathrm{m}$. All from isotype. 

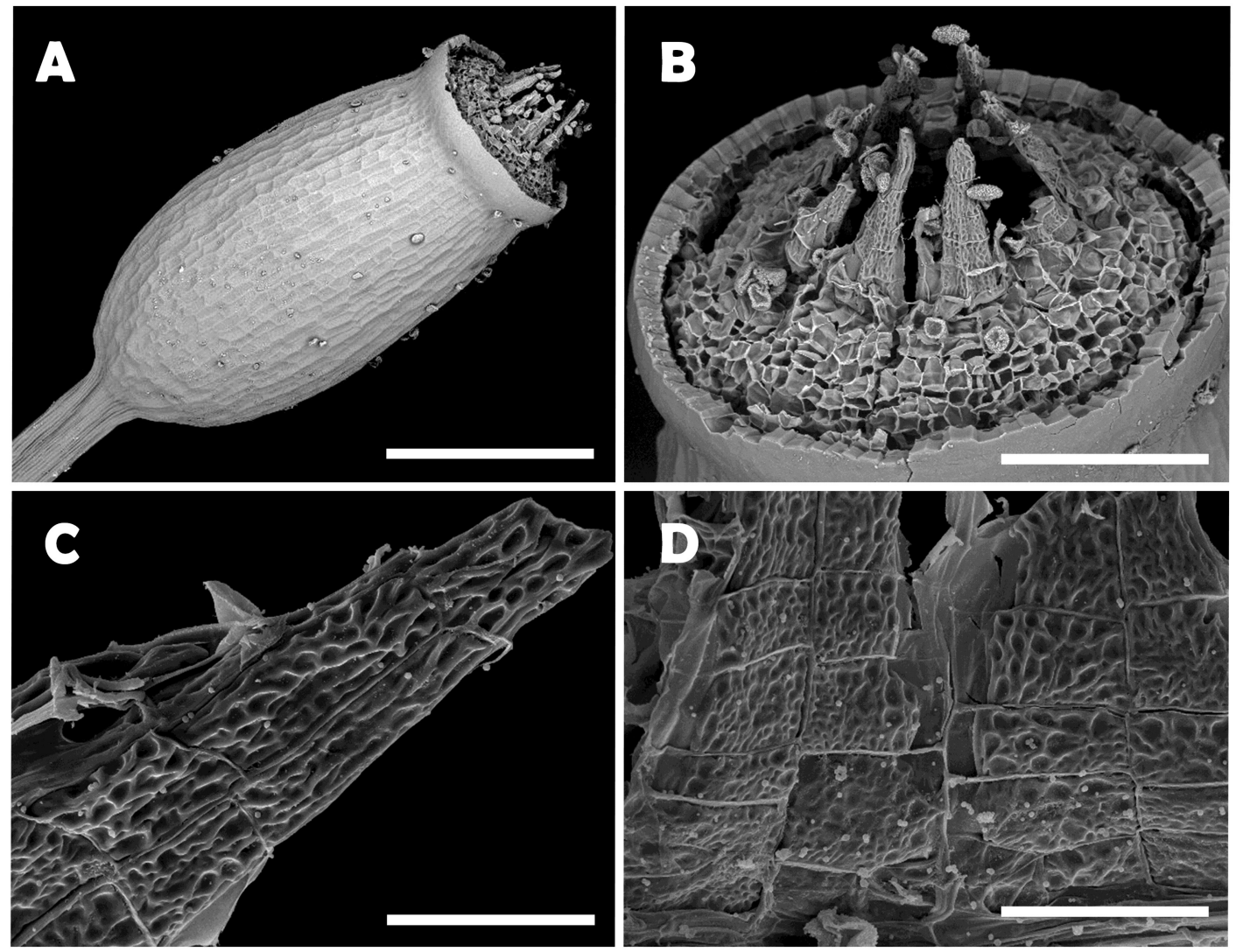

Figure 7. Scanning electron micrographs of sporophyte and peristome of Octoblepharum benitotanii Salazar Allen \& Chantanaorr., sp. nov. A. Whole capsule with prostome and peristome dorsal (outer) surface; B. Surface view of prostome and peristome; C. Ventral view (inner) of tooth near apex showing foveolate ornamentation; D. Ventral view (inner) of two teeth at base. Scales: $A=0.50 \mathrm{~mm}, B=0.15 \mathrm{~mm}, C=38.8$ $\mu \mathrm{m}, \mathrm{D}=48.9 \mu \mathrm{m}$. All from isotype.

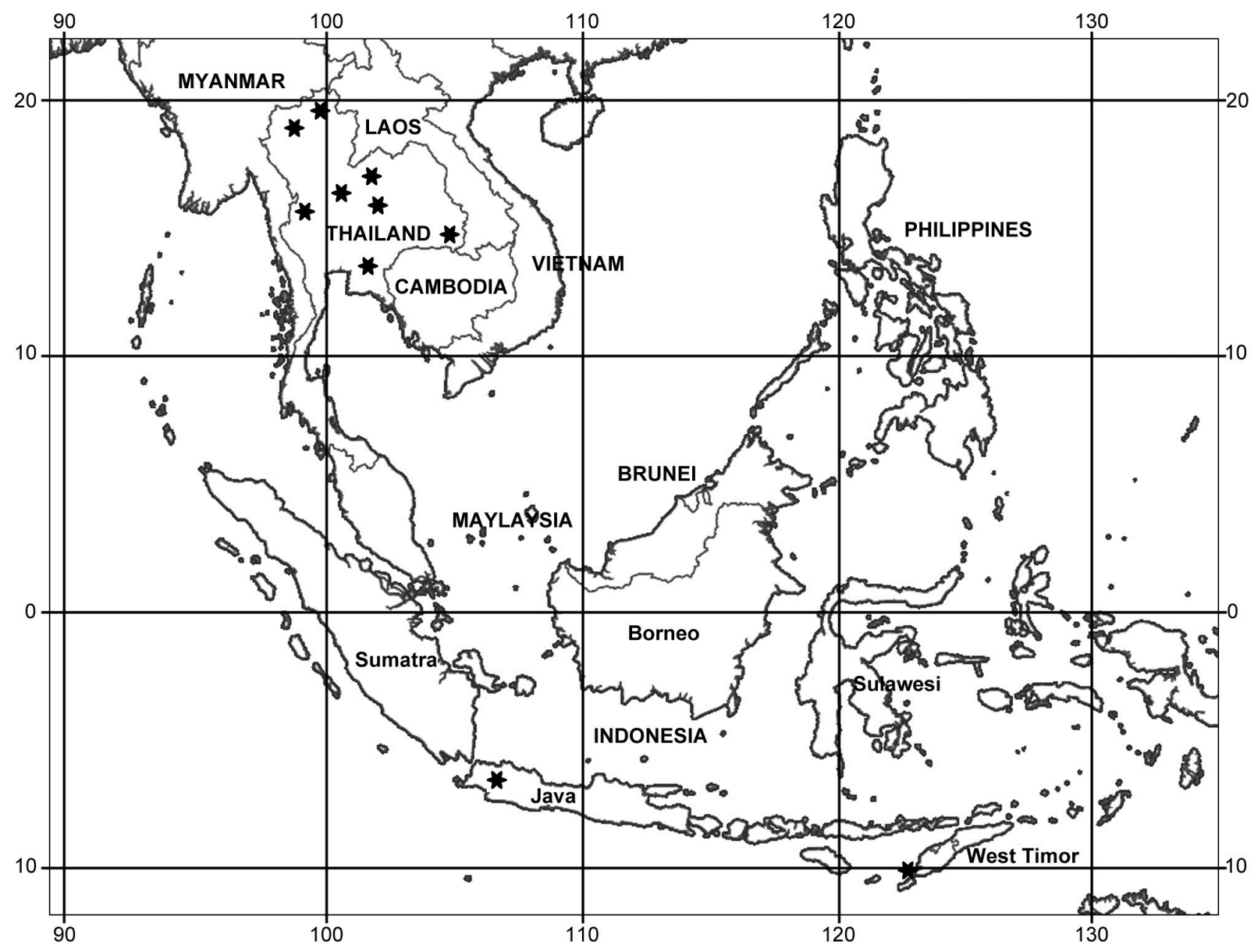

Figure 8. Distribution of Octoblepharum benitotanii Salazar Allen \& Chantanaorr., sp. nov. in Southeast Asia. 
species are very similar in their habit of dense whitish-green turfs, tumid, non-fragile leaves with inflated marginal hyalocysts, long hexagonal cells of hyaline lamina, autoicous condition and the presence of abundant sporophytes. Furthermore, in some instances the peristome of 0 . albidum can be perforated towards the base (Yano, 1992). Octoblepharum benitotanii differs, however, from 0 . albidum by the characters discussed in the diagnosis and by long versus short leaf acumen (illustrations of the leaf acumen of O. albidum are provided by Yano, 1992; Peterson, 1994; Churchill \& Salazar Allen, 2001; Buck, 2003; Reese, 2007); and by the strongly foveolate-reticulate peristome teeth on dorsal and ventral surfaces versus smooth to vertically striated to reticulated. Pictures of the peristome ornamentations in $O$. albidum have been provided (Magill, 1981; Eddy, 1990; Salazar Allen, 1992; Yano, 1992; Churchill \& Salazar Allen, 2001; He, 2014). The presence of single and serial inflated hyalocysts on leaf margins in $O$. benitotanii are also observed in the Neotropical 0 . cocuiense, 0 . stramineum, $O$. cylindricum, and $O$. rhaphidostegium. Of these, the first two have a peristome of 16 teeth whereas $O$. benitotanii has 8 teeth. Also, unlike $O$. benitotanii, $O$. cocuiense has long, fragile leaves with purple coloration and, $O$. stramineum has fragile leaves, which are stramineous above and a glossy, golden reddish-brown to orange-red at base. Octoblepharum cylindricum, unlike $O$. benitotanii, has slightly longer leaves, $4-6(-8) \mathrm{mm}$, that lack the prominent acumen, and possesses a longer seta, 10-18(-20) mm; nevertheless, the ornamentation of the eight-peristome teeth is foveolate-reticulate as in 0 . benitotanii but differs in including prominent trabeculae (Salazar Allen, 1992), not present in the new species. Octoblepharum rhaphidostegium although having leaves similar in size to the new species, has peristome teeth faintly striated with thickened vertical and transversal cell walls. Thus, among Octoblepharum species with eight peristome teeth, $O$. benitotanii has gametophytic characters closer to $O$. albidum and peristome ornamentation similar to $O$. cylindricum.

\section{Additional specimens examined (paratypes)}

THAILAND. Chiang Mai: Doi Suthep-Pui National Park, Doi Pui, 1685 m, 7 May 2009, Printarakul 693 (CMUB); San Ku, 1650 m, 30 May 2009, Printarakul 1193 (CMUB); Doi Mon Long Viewpoint, $1390 \mathrm{~m}, 4$ Nov 2015, Chantanaorrapint \& Juengprayoon 144 (PSU); Chiang Dao Wildlife Sanctuary, Doi Chiang Dao, 1449 m, 1 Nov 2013, Chantanaorrapint \& Promma 3221 (PSU); Pang Wua walking trail, 1577 m, 29 October 2017, Chantanaorrapint \& Suwanmala 2067 (PSU). Chiang Rai: Mae Fah Luang, Phra That Doi Tung, 1358 m, 6 Sep 2013, Chantanaorrapint \& Promma 2844 (PSU). Chaiyaphum: Phu Khiao Wildlife Sanctuary, walking trail to Ton Krang, 855 m,18 Aug 2015, Poopath 769 (BKF, PSU). Phitsanulok: Phu Hin Rong Kla National Park, 1327 m, 10
Dec 2013, Chantanaorrapint, Inuthai \& Promma 3449 (PSU). Loei: Phu Kradung National Park, Wang Kwang waterfall, 1200 m, 14 Nov 2017, Putthisawong 713 (PSU). Prachin Buri: Khao Yai National Park, Pha Deaw Dai, 1190 m, 13 Nov 2013, Chantanaorrapint \& Promma 3230 (PSU). Tak: Umphang, Tee Lor Su waterfall, $550 \mathrm{~m}, 14$ Aug 2013, Rapeeprasit 3 (PSU); Doi Hua Mot, 850 m, 14 Aug 2013, Rapeeprasit 6 (PSU). Ubon Ratchathani: Pha Tam National Park, Seang Chan waterfall, $151 \mathrm{~m}, 19$ Jun 2016, Chantanaorrapint, Juengprayoon \& Suwanmala 382 (PSU). INDONESIA. East Nusa Tenggara (West Timor). Kupang Bay. Pari ti an d. Kupang Bay (locality as it appears in the original label), 23 May 1875, Gazelle-Expedition (M)West Java Province. Tjiliwong pr. Bogor (as it appears in the original label), 830, IV.61. Kurz 902 (M).

\section{AKNOWLEDGEMENTS}

This study was supported by research and travel funds to $\mathrm{N}$. Salazar Allen (NSA) by the Smithsonian Tropical Research Institute (STRI) of Panama and by Prince of Songkla University Research Fund Contract no. SCI610148S to S. Chantanaorrapint (SC). We are thankful to Directors of M, CMUB, PSU herbaria for loan of specimens. Line drawings and photo of habit are the work of SC. Thanks are also due to J. Gudiño L., STRI research technician for help in processing samples and preparing the plates, and to $\mathrm{J}$. Ceballos, SEM technician at STRI. Our sincere thanks to Dr. I. Valdespino for his comments and revision of the first draft of the manuscript and to two anonymous reviewers.

\section{LITERATURE CITED}

Buck, W.R., 2003. Guide to the Plants of Central French Guiana. Part 3. Mosses. Memoirs of the New York Botanical Garden 76, part 3. P. 35, Fig. 33.

Churchill, S.P. \& N. Salazar Allen, 2001. Mosses: Keys and Descriptions. Octoblepharum albidum Hedw. In Guide to the Bryophytes of Tropical America. Gradstein, S.R., S.P. Churchill \& N. Salazar-Allen. P. 403.

Crum, H.A., 1983. Octoblepharum costatum. In Magdefrau, $\mathrm{K}$. The bryophyte vegetation of the forests and paramos of Venezuela and Colombia. Nova Hedwigia, 38: 54, Fig. 3.

Eddy, A., 1990. A Handbook of Malesian Mosses. Vol. 2, Leucobryaceae to Buxbaumiaceae. Natural History Museum Publications. P. 32, Fig. 186.

Egunyomi, A., A.J. Harrington \& S.O. Olarinmoye, 1977. Is Octoblepharum brevisetum Townsend a distinct species? Journal of Bryology, 9(4): 525-527.

Frahm, J.-P., 1994. A contribution to the bryoflora of the Chocó region, Colombia. I. Mosses. Tropical Bryology, 9: 89-110. 
He, S., 2014. Octoblepharum pocsii (Calymperaceae), a recently described African moss species new to Laos and Asia. Phytotaxa, 184: 178-180.

Magill, R.E., 1981. Bryophyta. Part 1. Mosses. Fascicle 1. Sphagnaceae-Grimmiaceae. In Flora of Southern Africa. Botanical Research Institute, Department of Agriculture and Fisheries, Republic of South Africa. Pp. 161-163.

Magill, R.E. \& B. Allen., 2013. Octoblepharum pocsii sp. nov. A fragile - and long-leaved species in the $O$. albidum complex from Africa. Polish Botanical Journal, 58(1): 4547.

Peterson, W., 1994. Leucobryaceae. 4. Octoblepharum Hedw. In Sharp A.J., H. Crum \& P. Eckel eds.) Moss Flora of Mexico. Part I, Sphagnales to Bryales. P. 184, Fig. 137.

Reese, W.D., 2007. Flora of North America Editorial Committee (ed.). Flora of North America North of Mexico 27. Bryophyta, pt.1. P.p. New York, Oxford: Oxford University Press.

Salazar Allen N., 1991. A preliminary treatment of the Central American species of Octoblepharum (Musci, Calymperaceae). Tropical Bryology, 4: 85-97.

Salazar Allen, N., 1992. Notas para la revisión de las especies de Octoblepharum del neotrópico. Tropical Bryology, 6: 171-179.

Salazar Allen, N., 1993. A revision of the pantropical moss genus Leucophanes Brid. J. Cramer, Berlin, Germany. $281 \mathrm{pp}$.

Salazar Allen, N., 1994. Octoblepharum. In: Allen, B. (ed.), Moss Flora of Central America. Part 1. SphagnaceaeCalymperaceae. Monographs in Systematic Botany. Missouri Botanical Garden 49: 182-191.

Salazar Allen, N. \& B.C. Tan, 2010. Octoblepharum arthrocormoides (Calymperaceae) N. Salazar Allen \& B.C. Tan, sp. nov., a new species from Tropical Asia. Botany 88: 439-442.

Thiers, B., 2018 (continuously updated). Index Herbariorum: A global directory of public herbaria and associated staff. New York Botanical Garden's Virtual Herbarium. http:// sweetgum.nybg.org/ih/ [accessed 29.01.2018].

Townsend, C.C., 1963. Octoblepharum brevisetum sp. nov. and Micromitrium sarcotrichum in Nigeria. Transactions of the British Bryological Society, 4: 434-436.

Wijk. R van der, W.D. Margadant, P.A. Florschütz (eds.), 1964. Index Muscorum 3. Regnum Vegetabile 33. International Association of Plant Taxonomy, Utrecht. Pp. 466-468.

Wijk, R van der, W.D. Margadant, P.A. Florschütz (eds.), 1969. Index Muscorum 5. Regnum Vegetabile 65. International Association of Plant Taxonomy, Utrecht. P. 790.
Yano O., 1992. Octoblepharum Hedw. In: Leucobryaceae (Bryopsida) do Brasil. Doctoral Thesis. Instituto de Biociências da Universidade de Sâo Paulo. Brasil. Pp.154-276. 